\title{
RENAL EXTRACTION AND EXCRETION OF MERCURY IN MAN FOLLOWING INTRAVENOUSLY ADMINISTERED MERCURIAL DIURETICS ${ }^{1}$
}

\author{
By R. E. WESTON, J. GROSSMAN, R. A. LEHMAN, T. D. ULlMANN, J. P. \\ HALPERIN, ${ }^{2}$ AND L. LEITER

\begin{abstract}
(From the Medical Division, Montefiore Hospital and the Department of Therapeutics, New York University-Bellevue Medical Center, New York City)
\end{abstract}

(Submitted for publication June 18, 1951; accepted August 13, 1951)

Previous studies (1) from this laboratory have indicated that urinary excretion of mercury reaches a maximal value immediately following the intravenous injection of an organic mercurial diuretic and then falls rapidly, presumably as the plasma concentration of mercury decreases. Moreover, the dynamics of mercury excretion during the first four to six hours in a given individual are quite constant on repeated measurement and are not significantly affected by certain factors which either enhance or inhibit diuresis.

In the present study the mechanisms by which mercury is removed from the plasma and excreted in the urine and the relationship of this process to mercurial diuresis have been investigated in human subjects with the aid of simultaneous measurements of renal hemodynamics, urinary mercury and electrolyte excretion, and arterial and renal venous plasma mercury concentrations.

\section{MATERIALS AND METHODS}

Of the six patients in this group, four were presumably free from renal disease. One patient (S. F.) had only one (right) kidney; another (W. M.) was recovering from glomerulonephritis.

All studies were carried out in the post-absorptive state. A multi-holed, soft rubber catheter was inserted in the urinary bladder. After placing an indwelling needle into the femoral artery under local anesthesia (metycaine), appropriate solutions for the measurement of inulin or mannitol and PAH clearances were infused into an arm vein. Then, under fluoroscopic control, a cardiac catheter was placed into the right renal vein and the location of the tip doubly checked by determining the renal $\mathrm{PAH}$ extraction, as previously described (2). Following three or four control urine collection periods, $2 \mathrm{ml}$. (80 $\mathrm{mg}$. mercury) of a mercurial diuretic were injected intra-

1 Supported in part by grants from the National Heart Institute, U. S. Public Health Service, Campbell Pharmaceutical Co., and the Martha M. Hall Foundation.

2 Eli Lilly Research Fellow in Medicine. venously. To maintain a higher and better sustained plasma concentration of mercury, in three patients an additional $2 \mathrm{ml}$. of the mercurial were added to the inulinPAH solution, which was infused at approximately $4 \mathrm{ml}$. per minute. Thiomerin, which has no theophylline component that might modify the excretion of mercury, was given to five of the patients while Mercuzanthin was given to the sixth. Previous studies (3) have established that the renal action of Thiomerin is qualitatively and quantitatively similar to that of other mercurial diuretics.

Following the administration of the mercurial, periodic urine collections were continued at 15 to 20 minute intervals for the determination of renal clearances, and urinary electrolyte and mercury excretion. At appropriate intervals, simultaneous femoral arterial and renal venous blood samples were also collected for the determination of the renal extraction of inulin, PAH, and mercury. In one patient (W. M.), catheterization of the renal vein was not attempted.

The determinations of inulin, mannitol, PAH and electrolytes were carried out by standard methods, as previously described (1-3). The mercury analyses were performed in duplicate by the dithizone method, as modified by Gettler and Lehman (4). By this method, $0.1 \mathrm{mg}$. of mercury may be detected with 3 to 5 per cent error. Where low levels were anticipated, larger quantities of plasma were analyzed. Preliminary studies confirmed the observations of others (5) that mercury in blood must be entirely in the plasma because none is found in the washed red blood cells.

From the data, the following values were calculated for each collection period (Table I) :

$C_{\text {IN }}, C_{M}, C_{P A B}=$ the renal clearances of inulin, mannitol and $\mathrm{PAH}$, respectively, by the usual methods.

$E_{\mathbf{P A H}}=$ the renal extraction of $\mathrm{PAH}=\frac{(\mathrm{PAH})_{\mathbf{A}}-(\mathrm{PAH})_{\mathbf{R V}}}{(\mathrm{PAH})_{\mathbf{A}}}$, when $(\mathrm{PAH})_{\mathbf{A}}$ and $(\mathrm{PAH})_{\mathbf{R V}}=$ the simultaneous plasma concentrations within the femoral artery and right renal vein, respectively.

$R P F=$ the true renal plasma flow $=\frac{C_{P A B}}{E_{P A B}}$.

$\mathrm{UV}_{\mathrm{Bg}_{\mathrm{g}}}$ = the urinary excretion of mercury in $\mathrm{mg}$. per minute.

$\mathrm{C}_{\mathrm{Hg}_{\mathrm{g}}}=$ the renal clearance of mercury $=\frac{\mathrm{UV}_{\mathrm{Hg}_{\mathrm{g}}}}{\left(\mathrm{Hg}_{\mathrm{A}}\right)}$, when $\left(\mathrm{Hg}_{\mathrm{A}}\right)=$ the corresponding mean arterial plasma concentration.

$\mathrm{E}_{\mathrm{Hg}}=$ the true renal extraction of mercury calculated similarly to $E_{P A B}$ from the simultaneous femoral arterial and renal venous plasma concentrations. 
$E_{H_{g}}^{\prime}$ - the extraction of mercury calculated from $\mathrm{UV}_{\mathrm{BE}_{\mathrm{g}}}=$ the ratio of the mercury excreted in the urine to the mercury delivered per minute to the kidney.

Values for renal mercury uptake and excretion were determined from the following data in patient E.N. (Table II):

$\mathrm{Hg}_{\text {Aft }}=\mathrm{mg}$. of'mercury ${ }^{\mathrm{b}}$ brought to the kidneys per minute, $=\left(\mathrm{Hg}_{\mathrm{A}}\right)(\mathrm{RPF})$.

$\mathrm{HgEn}_{\mathrm{g}}=\mathrm{mg}$. of mercury leaving the kidneys per minute, $=\left(\mathrm{H}_{\mathrm{gV}}\right)(\mathrm{RPF})$ where $\left(\mathrm{H}_{\mathrm{gRV}}\right)=$ corresponding midperiod renal venous plasma mercury concentration.

$\mathrm{Hg}_{\mathrm{R}}=\mathrm{mg}$. of mercury removed from the blood by the kidneys per minute $=\mathrm{Hg}_{\text {Aff }}-\mathrm{Hg}$ Eff.

$\mathrm{Hg}_{B}=\left(\mathrm{Hg}_{\mathrm{R}}-\mathrm{UV}_{\mathrm{B}}\right) \mathrm{t}=$ total renal mercury balance for collection period $t$. A significant positive value indicates renal mercury retention (positive renal mercury balance), whereas a negative value reflects renal release of mercury (negative renal mercury balance).

\section{RESULTS}

The data on the six patients studied are summarized in Table I and Figures 1 and 2. Five to 10 minutes after the injection of $2 \mathrm{ml}$. of a mercurial diuretic the plasma concentrations of mercury varied from 0.6 to $1.1 \mathrm{mg}$. per $100 \mathrm{ml}$. in five subjects and was $1.5 \mathrm{mg}$. per $100 \mathrm{ml}$. in Patient S. F. who had one kidney (Figure 1). In the first 30 to 45 minutes the concentration fell rapidly and the rates of fall and the slopes of the curves were similar in all three patients. In the patients given an additional $2 \mathrm{ml}$. of the mercurial in the sustaining infusion, the plasma concentration de-

TABLE I

Renal hemodynamics and mercury excretion following mercurial diuretics

\begin{tabular}{|c|c|c|c|c|c|c|c|c|c|c|c|c|c|}
\hline Patient & Period & $\begin{array}{r}\text { Time } \\
\text { (min.) }\end{array}$ & $\underset{\substack{\left.\text { (ml. } \\
1.73 \text { MM. }^{2}\right)}}{\text { G.F.R. }}$ & 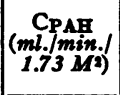 & EPAB & $\begin{array}{c}\text { True } \\
\text { R.P.F. } \\
\text { (mil./min.l } \\
\left.1.73 \mathrm{M}^{2}\right)\end{array}$ & $\underset{\text { (mg./min.) }}{\text { UVEp }}$ & $\underset{(\text { mg.\%) }}{(\mathbf{H g})}$ & 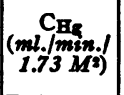 & $\begin{array}{c}\text { True } \\
\text { EEts }_{\text {B }}\end{array}$ & $\begin{array}{c}\text { Appar- } \\
\text { ent } \\
\mathbf{E}^{\prime} \mathbf{H g}\end{array}$ & 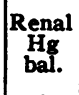 & Remarks \\
\hline H. S. & $\begin{array}{l}1 \\
2 \\
3 \\
4 \\
5 \\
6\end{array}$ & $\begin{array}{c}92-72 \\
72-42 \\
42-27 \\
27-0 \\
0-16 \\
16-39\end{array}$ & $\begin{array}{c}98.6(\mathrm{M}) \\
91.2 \\
94.4 \\
101.4 \\
98.9 \\
90.6\end{array}$ & $\begin{array}{l}674 \\
562 \\
611 \\
586 \\
519 \\
504\end{array}$ & $\begin{array}{r}0.91 \\
.83 \\
.80\end{array}$ & $\begin{array}{l}644 \\
626 \\
630\end{array}$ & $\begin{array}{r}0.81 \\
.54\end{array}$ & $\begin{array}{r}1.12 \\
.71\end{array}$ & $\begin{array}{l}74 \\
78\end{array}$ & $\begin{array}{c}0.17 \\
.0\end{array}$ & $\begin{array}{l}0.11 \\
0.12\end{array}$ & \pm & $\begin{array}{l}\text { Thiomerin } 2 \mathrm{ml} \text {. } \\
\text { i.v. }\end{array}$ \\
\hline S. F. & $\begin{array}{l}1 \\
2 \\
3 \\
4 \\
5 \\
6\end{array}$ & $\begin{array}{c}56-39 \\
39-16 \\
16-0 \\
0-17 \\
17-35 \\
35-48\end{array}$ & $\begin{array}{l}\mathbf{5 5 . 2 ( M )} \\
57.8 \\
57.3 \\
52.9 \\
48.8 \\
48.0\end{array}$ & $\begin{array}{l}356 \\
361 \\
314 \\
297 \\
334 \\
366\end{array}$ & $\begin{array}{l}.92 \\
.91 \\
.88 \\
.79 \\
.76\end{array}$ & $\begin{array}{l}392 \\
343 \\
338 \\
423 \\
481\end{array}$ & $\begin{array}{r}0.00 \\
.44 \\
.34 \\
.20\end{array}$ & $\begin{array}{r}1.45 \\
.93 \\
.63\end{array}$ & $\begin{array}{l}30 \\
37 \\
\mathbf{3 2}\end{array}$ & $\begin{array}{r}0.10 \\
.10 \\
.09\end{array}$ & $\begin{array}{l}0.09 \\
0.09 \\
0.07\end{array}$ & + & $\begin{array}{l}\text { Thiomerin } 2 \mathrm{ml} \text {. } \\
\text { i.v. }\end{array}$ \\
\hline A. W. & $\begin{array}{l}1 \\
2 \\
3 \\
4 \\
5 \\
6 \\
7\end{array}$ & $\begin{array}{c}71-60 \\
60-38 \\
38-0 \\
0-17 \\
17-34 \\
34-59 \\
59-75\end{array}$ & \begin{tabular}{|c|}
$105(\mathrm{M})$ \\
104 \\
82.4 \\
97.5 \\
68.2 \\
71.1 \\
73.0
\end{tabular} & $\begin{array}{l}532 \\
502 \\
370 \\
446 \\
303 \\
360 \\
628\end{array}$ & $\begin{array}{l}0.90 \\
.90 \\
.86 \\
.89\end{array}$ & $\begin{array}{l}411 \\
496 \\
353 \\
405\end{array}$ & $\begin{array}{r}0.21 \\
.28 \\
.21 \\
.17\end{array}$ & $\begin{array}{r}1.13 \\
.70 \\
.46\end{array}$ & $\begin{array}{l}19 \\
40 \\
46\end{array}$ & $\begin{array}{r}0.10 \\
.28 \\
.32\end{array}$ & $\begin{array}{l}0.08 \\
0.11 \\
0.11\end{array}$ & + & $\begin{array}{l}\text { Mercuzanthin } \\
2 \text { ml. i.v. }\end{array}$ \\
\hline G. W. & $\begin{array}{r}1 \\
2 \\
3 \\
4 \\
5 \\
6 \\
7 \\
8 \\
9 \\
10 \\
11 \\
12\end{array}$ & $\begin{array}{c}121-88 \\
88-64 \\
64-28 \\
28-0 \\
0-16 \\
16-34 \\
34-47 \\
47-63 \\
63-80 \\
80-97.5 \\
97.5-107 \\
107-133\end{array}$ & $\begin{array}{c}98.6(I) \\
90.2 \\
101 . \\
99.5 \\
88.0 \\
85.1 \\
123 . \\
100 . \\
105 \\
102 \\
103 \\
90.3\end{array}$ & $\begin{array}{l}594 \\
516 \\
598 \\
476 \\
404 \\
433 \\
669 \\
572 \\
575 \\
575 \\
632 \\
471\end{array}$ & $\begin{array}{r}0.93 \\
.92 \\
.87 \\
.84 \\
.85 \\
.85 \\
.84 \\
.85 \\
.88 \\
.88\end{array}$ & $\begin{array}{l}643 \\
540 \\
465 \\
515 \\
787 \\
673 \\
674 \\
676 \\
718 \\
535\end{array}$ & $\begin{array}{r}0.59 \\
.68 \\
.62 \\
.41 \\
.40 \\
.36 \\
.36 \\
.34\end{array}$ & $\begin{array}{r}\mathbf{0 . 6 1} \\
.49 \\
.50 \\
.55 \\
.59 \\
.54 \\
.51\end{array}$ & $\begin{array}{r}98 \\
139 \\
124 \\
75 \\
68 \\
67 \\
71\end{array}$ & $\begin{array}{r}\mathbf{0 . 3 8} \\
.36 \\
.35 \\
.33 \\
.32 \\
.33 \\
.36\end{array}$ & $\begin{array}{l}0.21 \\
0.27 \\
0.16 \\
0.11 \\
0.10 \\
0.10 \\
0.10\end{array}$ & $\begin{array}{l}+ \\
+ \\
+ \\
+\end{array}$ & $\begin{array}{l}\text { Thiomerin } 2 \mathrm{ml} \text {. } \\
\text { i.v. }+2 \mathrm{ml} \text {. in } \\
\text { infusion, whole } \\
\text { blood } 5 \mathrm{ml} \text {./ } \\
\text { min. }\end{array}$ \\
\hline E. N. & $\begin{array}{r}1 \\
2 \\
3 \\
4 \\
5 \\
6 \\
7 \\
8 \\
9 \\
10 \\
11\end{array}$ & $\begin{array}{c}76-52 \\
52-39 \\
39-25 \\
25-0 \\
0-18 \\
18-32 \\
32-58 \\
58-84 \\
84-104 \\
104-128 \\
128-150\end{array}$ & $\begin{array}{l}178(\mathrm{I}) \\
154 \\
174 \\
133 \\
154 \\
142 \\
139 \\
154 \\
142 \\
122 \\
137\end{array}$ & $\begin{array}{l}867 \\
786 \\
864 \\
701 \\
756 \\
703 \\
737 \\
784 \\
782 \\
646 \\
705\end{array}$ & $\begin{array}{r}0.91 \\
.89 \\
.89 \\
.89 \\
.89 \\
.89 \\
.87 \\
.86 \\
.87 \\
.87 \\
.87\end{array}$ & $\begin{array}{l}952 \\
883 \\
970 \\
788 \\
850 \\
790 \\
847 \\
911 \\
899 \\
743 \\
810\end{array}$ & $\begin{array}{r}0.78 \\
.80 \\
.51 \\
.37 \\
.29 \\
.24 \\
.26\end{array}$ & $\begin{array}{r}0.80 \\
.71 \\
.63 \\
.56 \\
.52 \\
.47 \\
.45\end{array}$ & $\begin{array}{r}125 \\
123 \\
90 \\
72 \\
62 \\
56 \\
64\end{array}$ & $\begin{array}{l}0.15 \\
.14 \\
.11 \\
.07 \\
.05 \\
.0 \\
.0\end{array}$ & $\begin{array}{l}0.12 \\
0.14 \\
0.10 \\
0.07 \\
0.06 \\
0.07 \\
0.07\end{array}$ & $\begin{array}{l}+ \\
\mathbf{0} \\
\mathbf{0} \\
0 \\
\mathbf{0} \\
- \\
-\end{array}$ & $\begin{array}{l}\text { Thiomerin } 2 \mathrm{ml} \text {. } \\
\text { i.v. }+2 \mathrm{ml} \text {. in } \\
\text { infusion, whole } \\
\text { blood } 5 \mathrm{ml} . / \\
\text { min. }\end{array}$ \\
\hline W. M. & $\begin{array}{r}1 \\
2 \\
3 \\
4 \\
5 \\
6 \\
7 \\
8 \\
9 \\
10\end{array}$ & $\begin{array}{c}130-85 \\
85-59 \\
59-35 \\
35-0 \\
0-22 \\
22-47 \\
47-68 \\
68-88 \\
88-112.5 \\
112.5-135.5\end{array}$ & $\begin{array}{l}86.3(I) \\
97.6 \\
96.5 \\
99.4 \\
88.8 \\
79.8 \\
79.4 \\
80.2 \\
61.0 \\
44.2\end{array}$ & & & & $\begin{array}{r}0.57 \\
.54 \\
.27 \\
.19 \\
.093 \\
.072\end{array}$ & $\begin{array}{c}1.1 \\
.57 \\
.54 \\
.52 \\
.50 \\
.48\end{array}$ & $\begin{array}{l}52 \\
95 \\
50 \\
37 \\
19 \\
15\end{array}$ & & & & $\begin{array}{l}\text { Thiomerin } 2 \mathrm{ml} \text {. } \\
\text { i.v. }+2 \mathrm{ml} \text {. in } \\
\text { infusion }\end{array}$ \\
\hline
\end{tabular}

(M)-Mannitol clearance.

(I)-Inulin clearance. 


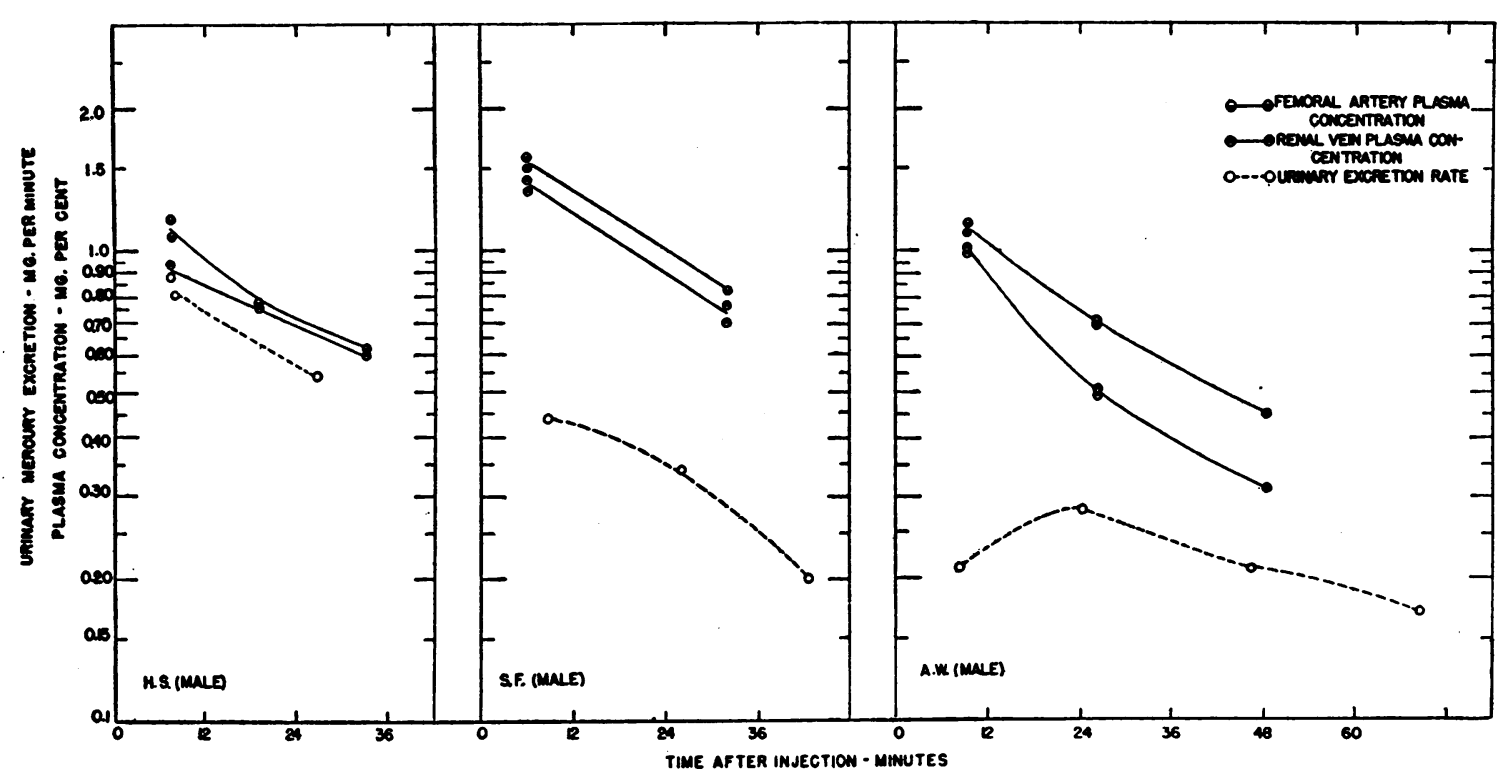

Fig. 1. Femoral Arterial and Renal Venous Plasma Mercury Concentrations and Urinary Mercury Excretion Rates After the Intravenous Injection of 2 mL. of a Mercurial Diuretic at Zero Time

Thiomerin was given to Patients H. S. and S. F. and Mercuzanthin to Patient A. W. The results of duplicate determinations are plotted for the respective plasma samples.

creased more slowly and was maintained at a measurable level even after 120 minutes (Figure 2).

As a rule, mercurials do not produce any marked, persistent effects on renal hemodynamics (3). However, with relatively low and rapidly falling plasma concentrations of mercury, the withdrawal of progressively larger samples of both arterial and renal venous blood was required to achieve analytical accuracy. As a result, the glomerular filtration rate sometimes decreased considerably during the course of the procedure. To counteract the adverse circulatory effects of such blood withdrawal, in two patients (G. W. and E. N.) whole blood transfusions at $5 \mathrm{ml}$. per minute were begun immediately after the mercurial was injected. In both cases the renal circulation was better maintained (Table I).

The renal clearance of mercury varied from $1 / 2$ to $3 / 4$ of the glomerular filtration rate. However, in the presence of rapidly changing plasma concentrations, the accuracy of clearance measurements is reduced.

In the five patients in whom renal PAH extraction was measured, this function fell significantly as a result of mercurial action. The decrease occurred before the outset of electrolyte and water diuresis and contributed to the observed decrease in $\mathrm{PAH}$ clearance.

The true renal extraction of mercury ranged from 0.1 to 0.4 . In $E$. N., whose renal venous and arterial plasma concentrations were determined over the longest period, the renal extraction of mercury decreased during the course of the procedure and was negligible after two hours.

In Table $I$ are given the true renal mercury extraction, $\mathrm{E}_{\mathrm{Hg}}$, based on the simultaneous femoral arterial and renal venous plasma mercury concentrations, and the apparent renal extraction of mercury, $E^{\prime}{ }_{\mathbf{H g}}$, the ratio of mercury excreted in the urine to mercury brought to the kidney per minute. These two calculated mercury extractions should be equal when the mercury received from the blood is promptly excreted in the urine. Whenever the mercury is either retained by or released from the renal parenchyma the true extraction will be correspondingly greater than or less than the apparent extraction.

In the early periods the true extraction was significantly greater than the apparent extraction but in the later periods tended to be equal to or less than the apparent extraction. This suggests that at first there is a positive renal balance or fixation of mercury by the kidney parenchyma with a later 


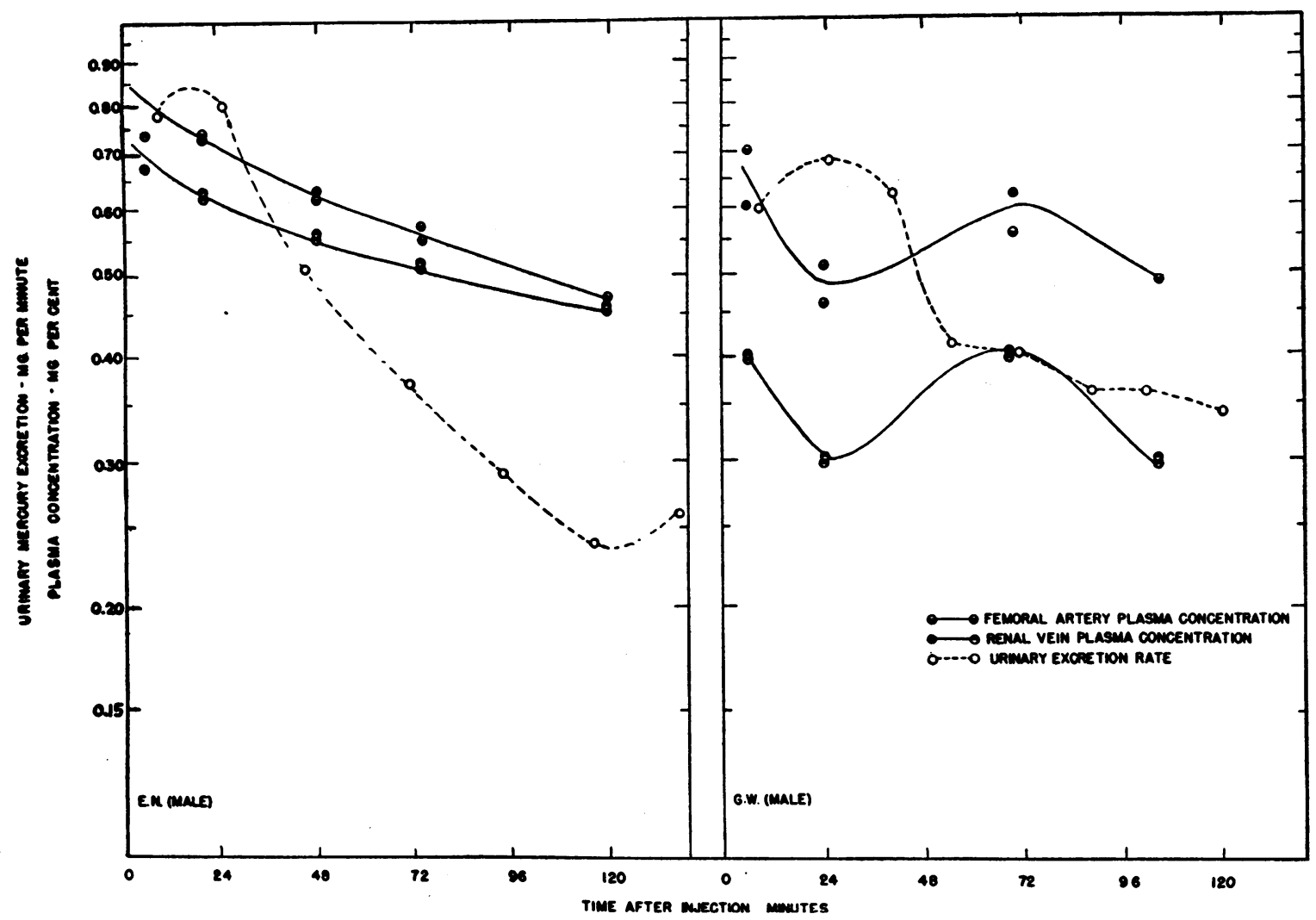

Fig. 2. Femoral Arterial and Renal Venous Plasma Mercury Concentrations and Urinary Mercury ExCRetion Rates After the Intravenous Injection of 2 mL. of Thiomerin and Addition of 2 mL. of Thiomerin to a Sustaining Infusion at Zero Time

The results of duplicate determinations are plotted for the respective plasma samples.

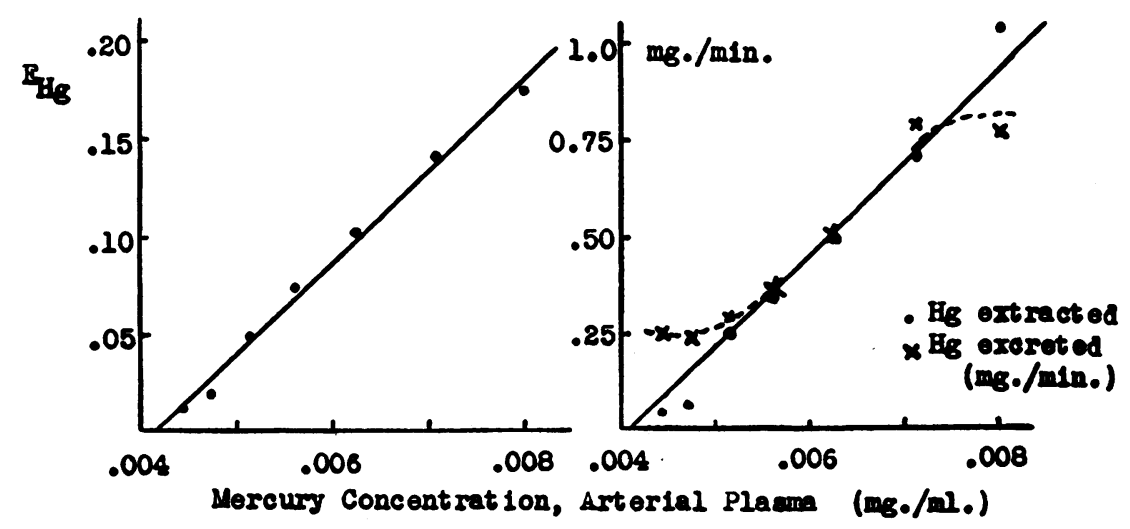

Fig. 3. Relationship Betwegn the Arterial Plasma Mercury Concentration and True Renal. Mercury Extraction (E $\left(\mathrm{UV}_{\mathrm{Bg}}\right)$

Plotted on the same graph as $\mathrm{UV}_{\mathrm{Bg}}$ are the calculated values for mercury removed from the blood by the kidney per minute, $\mathbf{H g}_{\mathrm{B}}$ (see Table II). 
TABLE II

Mercury uptake and release by the normal human kidney (Patient E. N.) following intravenous administration of an organic mercurial diuretic

\begin{tabular}{|c|c|c|c|c|c|}
\hline \multirow[b]{2}{*}{ Period } & \multirow{2}{*}{$\begin{array}{l}\text { Dura- } \\
\text { tion } \\
\text { (min.) }\end{array}$} & \multirow{2}{*}{$\begin{array}{c}\text { Urine } \\
\text { flow } \\
\text { (ml./min.) }\end{array}$} & \multicolumn{2}{|c|}{$\begin{array}{l}\text { Mercury removal } \\
\text { from blood }\end{array}$} & \multirow{2}{*}{$\begin{array}{c}\text { Renal } \\
\text { balance } \\
\text { (HgB) } \\
(\mathbf{m g} .)\end{array}$} \\
\hline & & & $\begin{array}{c}\text { Renal } \\
\text { uptake } \\
(\mathrm{Hg}) \mathrm{R} \\
(\boldsymbol{m g} . / \min .)\end{array}$ & $\begin{array}{c}\text { Urinary } \\
\text { excretion } \\
\text { (UVHe) } \\
(m g . / m i n .)\end{array}$ & \\
\hline $\begin{array}{l}1 \\
2\end{array}$ & $\begin{array}{l}24 \\
13\end{array}$ & $\begin{array}{l}3.17 \\
8.54\end{array}$ & \multirow[b]{4}{*}{$\begin{array}{r}1.09 \\
.72\end{array}$} & \multirow[b]{4}{*}{$\begin{array}{r}0.78 \\
.80\end{array}$} & \multirow[b]{4}{*}{$\begin{array}{l}+5.6 \\
-1.1 \\
\end{array}$} \\
\hline $\begin{array}{l}3 \\
4\end{array}$ & $\begin{array}{l}14 \\
25\end{array}$ & $\begin{array}{l}12.1 \\
7.08\end{array}$ & & & \\
\hline \multicolumn{3}{|c|}{$\begin{array}{l}\text { Thiomerin } 2 \mathrm{ml} \text {. i.v. and } \\
2 \mathrm{ml} \text {. added to infusion, } \\
\text { whole blood }-5 \mathrm{ml} . / \mathrm{min} \text {. }\end{array}$} & & & \\
\hline $\begin{array}{l}5 \\
6\end{array}$ & $\begin{array}{l}18 \\
14\end{array}$ & $\begin{array}{l}3.56 \\
4.71\end{array}$ & & & \\
\hline $\begin{array}{l}7 \\
8\end{array}$ & $\begin{array}{l}26 \\
26\end{array}$ & $\begin{array}{l}5.77 \\
5.69\end{array}$ & $\begin{array}{l}.50 \\
.35\end{array}$ & $\begin{array}{l}.51 \\
.37\end{array}$ & $\begin{array}{l}-0 \\
-0\end{array}$ \\
\hline $\begin{array}{r}9 \\
10 \\
11\end{array}$ & $\begin{array}{l}20 \\
24 \\
22\end{array}$ & $\begin{array}{l}9.05 \\
3.50 \\
2.09\end{array}$ & $\begin{array}{l}.21 \\
.06 \\
.04\end{array}$ & $\begin{array}{l}.29 \\
.24 \\
.26\end{array}$ & $\begin{array}{r}-1.6 \\
-4.3 \\
-4.8 \\
-6.2\end{array}$ \\
\hline
\end{tabular}

negative renal balance as the mercury is released and excreted into the urine.

In Table II, the data for renal mercury uptake, excretion and balance in patient E. N. are presented. These also reflect early retention and subsequent release of mercury by the kidneys.

\section{DISCUSSION}

As a consequence of the rapid early excretion of mercury, a significant fraction of the total mercury administered is eliminated before the onset of diuresis (1). However, the present chemical methods measure only total mercury in the blood and urine. When it becomes possible to determine the chemical changes undergone by a mercurial diuretic in the body, it may prove feasible to distinguish diuretically active and inactive fractions of the mercury excreted in the urine.

The present values for renal clearance of mercury in man are similar to those reported by Burch and coworkers (6). However, in the two of our patients (G. W. and E. N.) in whom mercury excretion was followed longest the clearance tended to fall to a lower but constant level during the first two hours. While Burch and coworkers (6) state that mercury clearance is fairly constant, it should be noted that their figures do not include the first 30 minute period. Moreover, some of their patients also exhibited a progressive fall in renal mercury clearance during the first two hours, which then tended to stabilize or even to rise slightly. Since a substance excreted simply by filtration would have a renal extraction of 0.2 , the extractions reported in Table $\mathrm{I}$ are in keeping with clearances of $1 / 2$ to $3 / 4$ the filtration rate. Such data might suggest that mercury is excreted by a process of filtration and partial tubular reabsorption, but factors such as renal storage, protein binding, or limited tubular excretion of mercury make this inference untenable.

That the mercury of injected organic mercurial compounds readily becomes albumin bound is generally accepted. Hughes (7) demonstrated that addition of mercuric chloride to a solution of albumin produces crystallization, the maximal yield resulting from adding $1 / 3 \mathrm{~mol}$ of mercuric chloride per mol of albumin. Furthermore, excess mercuric chloride, as well as certain sulfhydryl compounds, brought about the disappearance of these crystals which were a complex of $1 \mathrm{~mol}$ of mercury per 2 mols of albumin.

Calculation of the plasma molarity of albumin and mercury demonstrates that stoichiometrically the molar concentration of albumin $(0.00066 \mathrm{M})$ is more than sufficient to bind all of the mercury present. For the amount of drug usually injected in a normal subject the maximal expected concentration of mercury would be approximately 0.0001 M. Actually, in the first plasma samples drawn within five minutes after the injection, the mercury concentration was $0.00004 \mathrm{M}$, or about 40 per cent of the theoretical value. Apparently, a large fraction of the injected mercury is promptly lost from the plasma (6), probably to the kidneys and other tissues. Such a loss may occur immediately following the injection of the mercurial before complete mixing is possible. However, the presence of other plasma proteins, the $\mathrm{pH}$, the dissociation constant of the mercury-albumin complex, and above all, its filterability at the glomeruli, remain to be evaluated. 
In this respect, the data on Patient E. N. may be relevant. From Figure 3, it is apparent that, as reported by Milnor and associates (8), a direct linear relationship exists between the arterial plasma mercury concentration and the renal extraction of mercury. This relationship is consistent with protein or other binding of mercury. If only a fraction or fixed amount of the injected mercury were protein bound and the remainder were either filterable or otherwise readily eliminated by the kidneys, the renal extraction would be greater the higher the plasma mercury concentration, because it would be a function of the concentration of "free" mercury. Acceptance of this hypothesis permits an additional inference to be drawn from the linear relationship between plasma concentration and renal extraction (Figure 3 ). The intercept between this line and the axis of abscissae may represent that plasma concentration of mercury at which virtually all the metal is so bound as to be unfilterable by the kidneys.

On the basis of in vitro studies in which the concentrations of mercury were much greater, Milnor (9) has reported that the percentage of free mercury in albumin solutions falls sharply as the concentration of mercury decreases. At the concentration found in patients, almost complete binding of mercury in the plasma would be anticipated. However, Milnor points out that even at very low plasma concentrations, a small fraction of the mercury is free and presumably filterable. If the two forms of mercury were in equilibrium with each other, the removal of any free mercury would result in further dissociation of the mercury complex. Any inferences drawn from Milnor's figures must be limited by several reservations since certain in vivo conditions are not duplicated by in vitro studies. For example, glutathione or other sulfhydryl containing constituents of plasma may bind the mercury more readily than does protein. The resulting compounds may certainly influence dissociation of, and may be more completely filtered than, the protein-mercury complex.

From Tables I and II it is evident that during the first collection period, despite the rapid excretion of mercury in the urine, the mercury removed by the kidneys was significantly greater than that eliminated; that is, renal mercury balance was positive. Conversely, in some patients the amount appearing in the urine after two hours was considerable, whereas the arterio-venous difference was no longer measurable; that is, renal mercury balance was negative. The source of the mercury excreted during the last two periods must have been the kidney itself. Thus, the conclusion appears inescapable that the usual clearance concept cannot be applied to the renal excretion of mercury because fixation of mercury by renal tissue and subsequent release must occur. Such fixation appears to be a rapid process, whereas the release is probably protracted.

Lehman, Barrack, and Lehman (10) have recently shown that mercurial diuretics of either the theophylline or mercaptide type undergo rupture of the carbon-mercury bond when treated in vitro with the dithiol, BAL. Some, at least, of the enzymes bearing essential sulfhydryl groups have two or more of these groups on the same molecule. Hence, the following mechanism for binding of a mercurial diuretic by kidney tissue would appear plausible.

$\mathrm{RHg}-\mathrm{S}-\mathrm{CH}_{2} \mathrm{COONa}$ (or $\mathrm{RHg}$-theophylline, or $\mathrm{RHg}-\mathrm{S}$-albumin) + Enzyme $(\mathrm{SH})_{2} \rightarrow$ (Enzyme) - $\mathrm{S}>\mathrm{Hg}+\mathrm{HgCH}_{2} \mathrm{COONa}$ (or theophylline; or albumin)

Abrupt suppression of mercurial diuresis can be effected by BAL and may be presumed to be due to removal of the mercury from the enzyme-mercury complex. Furthermore, as the mercury levels in the plasma or glomerular filtrate fall to low values, it would appear possible for simple thiols such as cysteine or glutathione to cause the regeneration of the enzyme and excretion of the mercury.

Inspection of Table II reveals also that the total renal mercury balance appears to be negative in a patient who had never received mercury previously and whose control urine contained no mercury. This apparent discrepancy may result from the following considerations: The amount of mercury brought to the kidneys during each urine collection period is calculated on the basis of the midperiod arterial plasma concentration. For the most part, since the curve is smooth and not falling rapidly, such interpolation is sufficiently accurate. However, the first urine collection period includes the period of mixing of the injected mer- 
curial when there is a much higher plasma concentration than that reflected by the mid-period level derived from subsequent blood sampling. Therefore, during the time of mixing, when the unsaturated mercury binding systems are most available, the amount taken up by the kidneys may be much greater than that calculated from the subsequent smooth portion of the curve. Consequently, in the period immediately following the injection, the kidneys are in even greater positive balance than can be determined by the present methods, and, as a result, more mercury is available for later release into the urine.

\section{SUM MARY}

By simultaneous clearance studies and renal vein catheterization in man, renal hemodynamics and the renal extraction and excretion of mercury were studied following intravenously administered mercurial diuretics.

Five to 10 minutes after the injection, arterial plasma mercury concentration ranged from 0.6 mg. per $100 \mathrm{ml}$. to $1.5 \mathrm{mg}$. per $100 \mathrm{ml}$. and fell rapidly in the next 30 to 45 minutes.

After the injection of the mercurial, renal paraamino hippurate extraction was significantly reduced before the onset of diuresis.

The true renal mercury extraction, based on the renal arteriovenous difference $\frac{\left(\mathrm{Hg}_{\mathbf{A}}-\mathrm{Hg} \mathbf{v}\right)}{\mathrm{Hg}_{\mathbf{A}}}$, was usually greater in the early periods than the apparent extraction, based on the ratio of mercury excreted in the urine to that brought to the kidney $\frac{(\mathrm{UV})}{\left(\mathrm{Hg}_{\mathrm{A}}\right)(\mathrm{RPF})}$. Later, the true extraction tended to be equal to or less than the apparent extraction. These observations suggest that mercury is first stored in and later released by the renal parenchyma. On occasion, at fairly high arterial mercury levels, the true renal mercury extraction was negligible. This observation is consistent with the presence of significant amounts of non-filterable mercury in the blood.

Renal clearance of mercury, which was roughly $1 / 2$ to $3 / 4$ of the simultaneously measured glomerular filtration rate, tended to fall at first, and then to be maintained at a more constant level. However, because of protein binding and renal fixation of mercury, "clearance" in the usual sense would not seem to apply to the renal excretion of mercury.

\section{ACKNOWLEDGMENTS}

The authors wish to express their appreciation to Morris Wolfman, Lila Wolfman, Madie Ross, and Lillian Pollack for their technical assistance and cooperation.

\section{REFERENCES}

1. Grossman, J., Weston, R. E., Lehman, R. A., Halperin, J. P., Ullmann, T. D., and Leiter, L., Urinary and fecal excretion of mercury in man following administration of mercurial diuretics. J. Clin. Invest., 1951, 30, 1208.

2. Edelman, I. S., Zweifach, B. W., Escher, D. J. W., Grossman, J., Mokotoff, R., Weston, R. E., Leiter, L., and Shorr, E., Studies on VEM and VDM in blood in relation to renal hemodynamics and renal oxygen extraction in chronic congestive heart failure. J. Clin. Invest., 1950, 29, 925.

3. Grossman, J., Weston, R. E., Edelman, I. S., and Leiter, L., Studies on Thiomerin-a subcutaneously administerable mercurial diuretic. Circulation, 1950, 1, 508.

4. Gettler, A. O., and Lehman, R. A., A simplified procedure for the determination of mercury in urine. Am. J. Clin. Path., 1938, 8, 161.

5. Ray, C. T., Burch, G. E., Threefoot, S. A., and Kelly, F. J., The distribution of radiomercury of a mercurial diuretic in some of the body fluids of man. Am. J. Med. Sc., 1950, 220, 160.

6. Burch, G., Ray, T., Threefoot, S., Kelly, F. J., and Svedberg, A., The urinary excretion and biologic decay periods of radiomercury labeling a mercurial diuretic in normal and diseased man. J. Clin. Invest., 1950, 29, 1131.

7. Hughes, W. L., Jr., Albumin fraction isolated from human plasma as a crystalline mercuric salt. J. Am. Chem. Soc., 1947, 69, 1836.

8. Milnor, P., Burch, G., Ray, T., Threefoot, S., and Berenson, G., Considerations of renal, hepatic and extremital arteriovenous differences in concentration of radiomercury of a mercurial diuretic. J. Clin. Invest., 1950, 29, 72.

9. Milnor, J. P., Binding of the mercury of an organic mercurial diuretic by plasma proteins. Proc. Soc. Exper. Biol \& Med., 1950, 75, 63.

10. Lehman, J. F., Barrack, L. P., and Lehman, R. A., Reactions of mercurial diuretics with mono- and dithiols. Science, 1951, 113, 410. 